\title{
Cambrian of the Himalaya and the Peninsular India- Biozonation, Depositional Environments and Biogeographic Provinces
}

Department of Geology, Panjab University, Chandigarh 160014

* Corresponding author, Email: v_ruh@rediffmail.com

(Received : 9/07/2019; Revised accepted : 10/12/2019)

https://doi.org/10.18814/epiiugs/2020/020027

In the Indian Himalaya, the Cambrian sequences are exposed in the Lesser and Tethyan Himalayan zones ( LHZ and THZ). In the LHZ, the Cambrian biozonation is available at four stratigraphic intervals, i.e., at $\sim 542-$ $535 \mathrm{Ma}, \sim 524-513 \mathrm{Ma}, \sim 516 \mathrm{Ma}$, and $512 \mathrm{Ma}$. In the THZ, the Cambrian biozonation exists broadly at two stratigraphic intervals, i.e., 514-505 Ma (in the Spiti region and partially in the Kashmir region) and $\sim 505-$ $498 \mathrm{Ma}$ (in the Zanskar region and partially in the Kashmir region). The Indian Cambrian faunal elements share Gondwanan and peri-gondwanan affinities. The depositional environments of the Cambrian sediments of THZ and LHZ show a wide array of settings.

\section{Cambrian of the Himalaya and the Peninsular India}

In the Paleozoic succession of the Indian Himalaya, the Cambrian sequences, volumetrically form the most abundant rocks (Wadia, 1975; Brookfield, 1993). The Cambrian sequences occurs in two broad lithotectonic zones (i) the LHZ framed by the Main Boundary Thrust (MBT) in the south and the Main Central Thrust (MCT) in the north and, (ii) the THZ bounded by the Vaikrita Group rocks with tectonic / non-conformable contact with the Greater Himalayan Zone (GHZ) in the south and the Indus-Tsangpo Suture Zone (ITSZ) in the north.

The Cambrian sequences within each zone are classified according to the structural/topographic basin in which they occur. Myrow et al. (2009) suggested that the Greater Himalayan Zone (GHZ) also includes deformed Cambrian sedimentary rocks in its central part-a contention yet to be proved.

Rocks of the Cambrian age are also known from the craton of the peninsular part of the Indian plate i.e., the Bikaner-Nagaur region of the Rajasthan basin (Kumar and Pandey, 2008; 2010; Singh et al., 2014; Pandey et al., 2014, Ahmad and Kumar, 2014; Hughes, 2016; Sharma et al., 2018; Singh et al., 2019a). Fig. 1 illustrates locations of various Cambrian outcrops.
The Cambrian rocks in the THZ, from northwest to southeast, are exposed in the Kashmir, Zanskar-Spiti, and Kumaun-Garhwal regions (Hayden, 1904; Reed, 1910, 1934; Wadia, 1934; Kobayashi, 1934; Srikantia et al., 1980; Srikantia, 1981; Shah et al., 1980, 1988, 1991; Shah, 1982; 1993; Kumar and Singh, 1983; Kumar and Verma, 1987; Tiwari 1989, 1997; Whittington, 1986; Kacker and Srivastava, 1996; Jell and Hughes, 1997; Bhargava and Bassi, 1998; Myrow et al., 2006a, 2006b, 2016; 2018; Peng et al., 2009; Upadhyay and Parcha, 2012; Singh et al., 2014, 2015, 2016, 2017a, 2017b, Popov et al., 2015; Hughes, 2016; Gilbert et al., 2016; Hughes et al., 2018; Yin et al., 2018; Srikantia and Bhargava, 2018).

In LHZ, the Cambrian rocks are exposed in the core of the NWSE trending doubly-plunging synclines, i.e., Nigali Dhar, Korgai, Mussoorie, and Garhwal (Azmi et al., 1981; Bhargava, 1984; Singh and Rai, 1983; Bhatt et al., 1983, 1985; Kumar et al., 1987; Brasier and Singh, 1987; Mathur and Joshi, 1989; Joshi et al., 1989; Prasad et al., 1990; Bhargava et al., 1998; Hughes et al., 2005; Jell and Hughes, 1997; Desai et al., 2010; Tarhan et el., 2014, Singh et al., 2015, 2017a, 2017b, 2019).

The Marwar Supergroup ( 1200 m thick) in the Bikaner-Nagaur Basin (Peninsular India) incorporates the Neoproterozoic to early Cambrian sequence (Khan, 1971; Pareek, 1984; Kumar and Pandey, 2008, 2010; Srivastava, 2012; Singh et al., 2014; Pandey et al., 2014; Ahmad and Kumar, 2014; Sharma et al., 2018).

Beside these, the Cambrian sequence is also preserved in the Salt Range, Peshawar and Hazara regions in Pakistan Himalaya (Noetlingi; 1894; Redlich, 1899; Waagen, 1891; Schindewolf and Seilacher, 1955) and in Bhutan (Tangri and Pande, 1995, Tangri et al., 2003; Myrow et al., 2009, 2010; Hughes et al., 2011).

The present contribution provides a succinct updated summary of the Cambrian deposits of the Indian Himalaya and the peninsular India.

\section{Development of the Cambrian Geology in the Himalaya and the Peninsular India}

Pioneering monographic contributions to the Cambrian stratigraphy and palaeontology of Spiti were made by Hayden (1904), Reed (1910) and of Kashmir by Reed (1934). Subsequent, 

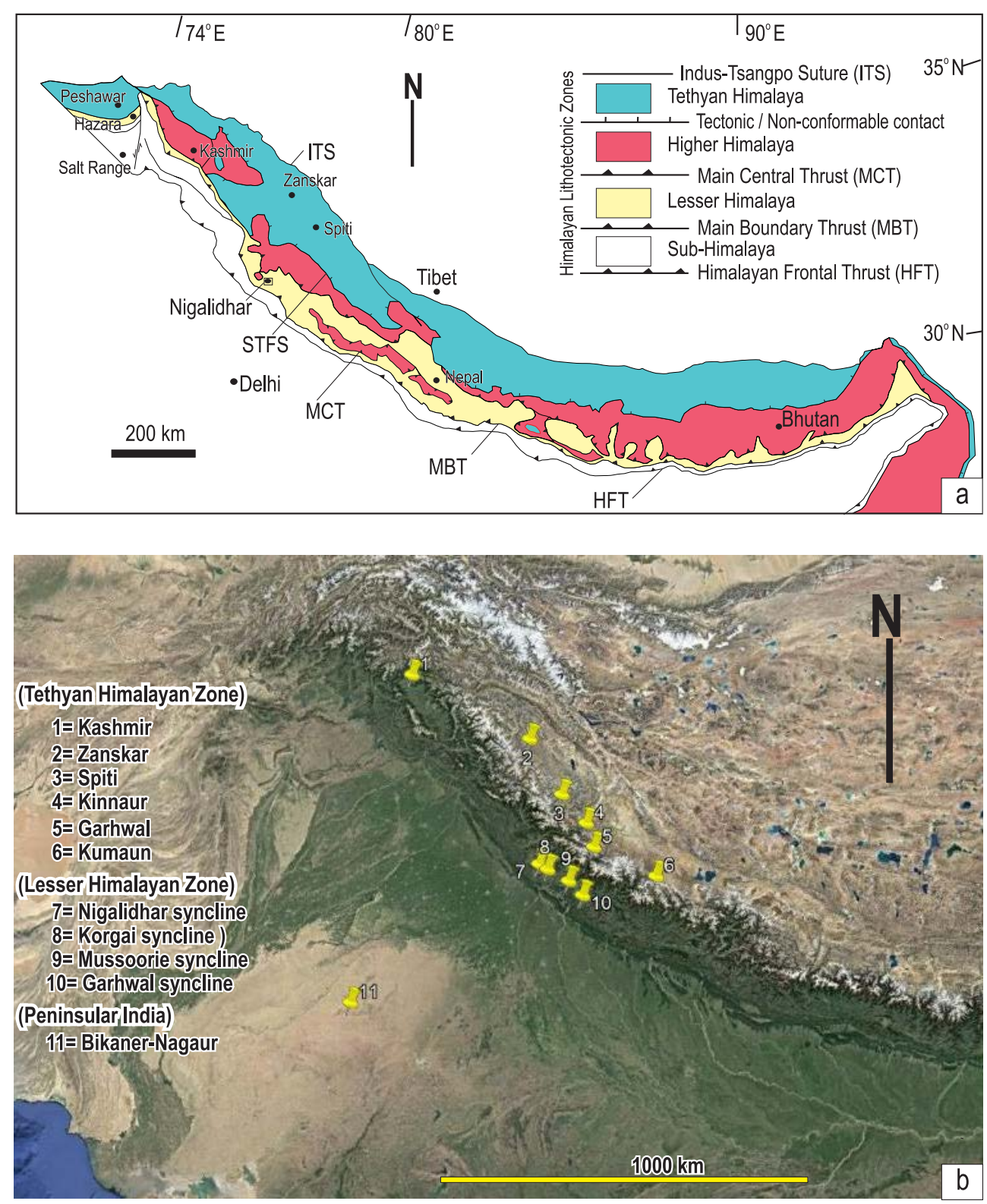

Figure 1(a) Different lithotectonic zones of the Himalaya, (b) Google-earth image showing the location of Cambrian successions in different part of the Himalaya and peninsular India.

contributions to the Cambrian lithostratigraphy, palaeontology and biostratigraphy between 1960 and 1995 came from the Geological Survey of India and the Jammu Universities (see Jell and Hughes, 1997; Hughes et al., 2005; Hughes, 2016 for synoptic review). These inputs pre-dated the modern global concepts; hence were revised by Jell and Hughes (1997) by re-naming the previously recorded faunal elements according to the latest development in the Cambrian palaeontology. Until 1997, the Himalayan Cambrian trilobite biostratigraphy remained inadequately understood due to poor (i) preservation of collected material, (ii) illustration of fossils, due to lack of sophisticated techniques and (iii) collections of fossils in remote terrains. In the last two decades, with improved communication in the Himalaya and advancement in the Cambrian palaeontology and biostratigraphy across the globe, the investigations in the Cambrian geology of the Himalaya received great incentive. The discovery of trilobites, small shelly fossils, brachiopods, and eocrinoids from the known and newly identified stratigraphic levels have contributed to a better understanding of the Cambrian biostratigraphy and biozonation of the Tethyan Himalaya Zone (Peng et al., 2009; Singh et al., 2015, 2016, 2017a, 2017b, 2019a; Popov et al., 2015; Gilbert et al., 2016; Hughes, 2016; Yin et al., 2018; Kaur et al., 2019).

The Tal Group, which yielded the Cambrian fossils in 1980s, was originally described as "Tal Limestone” by Medlicott (1864) and “Tal beds” by Middlemiss (1887). They were considered a JurassicCretaceous sequence (Medlicott, 1864; Middlemiss; 1887; Auden, 1934, 1937, Bhargava, 1972, 1976). The "Tal beds" were divided into lower and upper Tal by Middlemiss (1887). Auden (1934, 1937) also divided it in lower and upper (including the upper and almost entire lower parts of Middlemiss) parts. The “Tal Beds” unit was referred to as the Tal Formation by Bhargava (1972), which was upgraded to Tal Group and divided into three formations (Bhargava, 1979). Juyal (1979) described small shelly fossils (SSFs) from the Chertphosphorite horizon of the base of the Tal Group in the Maldeoata section (Mussoorie syncline). Azmi et al. (1981) published additional materials as Cambro-Ordovician small shelly fossils (SSFs). Subsequently, in the entire LHZ, the early Cambrian fossils were recorded from the Tal Group (Bhargava, 1984; Brasier and Singh, 1987; Kumar et al, 1987; Bhatt et al., 1983, 1985; Bhargava et al., 1998; Hughes et al., 2005).

Till recently, the Tal Group was assigned to early Cambrian, with an uncertain upper age limit (Hughes et al., 2005; Singh et al., 2019a). Discovery of Ordovician trace fossils constrains the upper age limit of the newly defined Tal Group to early Cambrian ( 512 Ma), which with an angular unconformity is followed by early Ordovician Deona Formation (Singh et al., 2019b).

The discovery of Cambrian trace fossils from the Nagaur Sandstone of the Bikaner-Nagaur region (Rajasthan basin) extends the Cambrian marine deposits to the cratonic part of the Indian plate (Kumar and Pandey, 2008, 2010). Though several workers reported the Cambrian trace fossils, yet the precise age of the Nagaur Sandstone (within the Cambrian) remains disputed. Some workers assigned a Terreneuvian-Series 2 age, while others preferred latest part of Cambrian Series 2/ Stage 4 (see Hughes, 2016; Pandey et al., 2014; Singh et al., 2013, 2014; Sharma et al., 2018; Singh et al., 2019a).

Identification of the various Cambrian stages, refinements of the 
biozonation and new discoveries from different sectors of the Himalaya and the peninsula have evoked keen interest the world over.

The Cambrian of the Himalaya and the Salt Range (Pakistan Himalaya) needs rigorous study to understand the genesis and distribution of the Cambrian rocks on the northern margin of the Indian plate.

\section{Cambrian biozonation}

Though the Cambrian period ( 541 to $485 \mathrm{Ma}$ ) lasted for 56 million years yet its biozonation in the Indian Himalaya is rather coarse and patchy. The Cambrian biozonation of the Himalaya and the Peninsular India is summarised in Table 1.

\section{Biozonation in the Himalaya}

The Cambrian deposits in the THZ are widely distributed and known from 21 valleys i.e.,Talar, Pohru, Lolab (in Kashmir), NiriTsarap Chu, Kurgiakh, Lunak, Karsha-Padam (in Zanskar), Baralacha and Chandra (Lahaul), Ratang, Parahio, Sumna, Pin (in Spiti), Baspa, Gymthiang and Tidong (in Kinnaur), Chorgad and Nelang (Jadhganga), Girthi Ganga, Gori Ganga and Kali valleys (in GarhwalKumaun regions).

The Parahio valley (Spiti), the best studied section, preserves only the latest Cambrian Series 2 / Stage 4 to Wuliuan Stage (Miaolingian Series), i.e., 512-505 Ma interval; base of the succession is truncated by a fault and its top has suffered a pre-Ordovician erosion. Fossils younger than 505 Ma are known from a float in the Spiti region (Reed, 1910; Jell and Hughes, 1997). Recognition of 512 to 505 Ma interval is based on four biozones and two levels of trilobites, small shelly and brachiopods fauna, viz., Haydenaspis parvatya level ( 511-510 Ma), (ii) Oryctocephalus indicus biozone ( 509 Ma), Kaotaia prachina biozone ( 508 Ma), Paramecephalus defossus biozone (507 Ma), Oryctocephalus salteri biozone (506 Ma), and Iranoleesia butes level (505 Ma). Agnostus spitiensis and Paranomocarella conjunctiva ( 502-500 Ma) are reported only from a float. Thus, the upper part of the Cambrian deposits of the Parahio valley remains undated. Since the Redlichia noetlingi ( $\sim 512 \mathrm{Ma})$ in the Pin valley is also from a

Table 1. Biozonation of the Cambrian of the Himalaya and the Peninsular India.

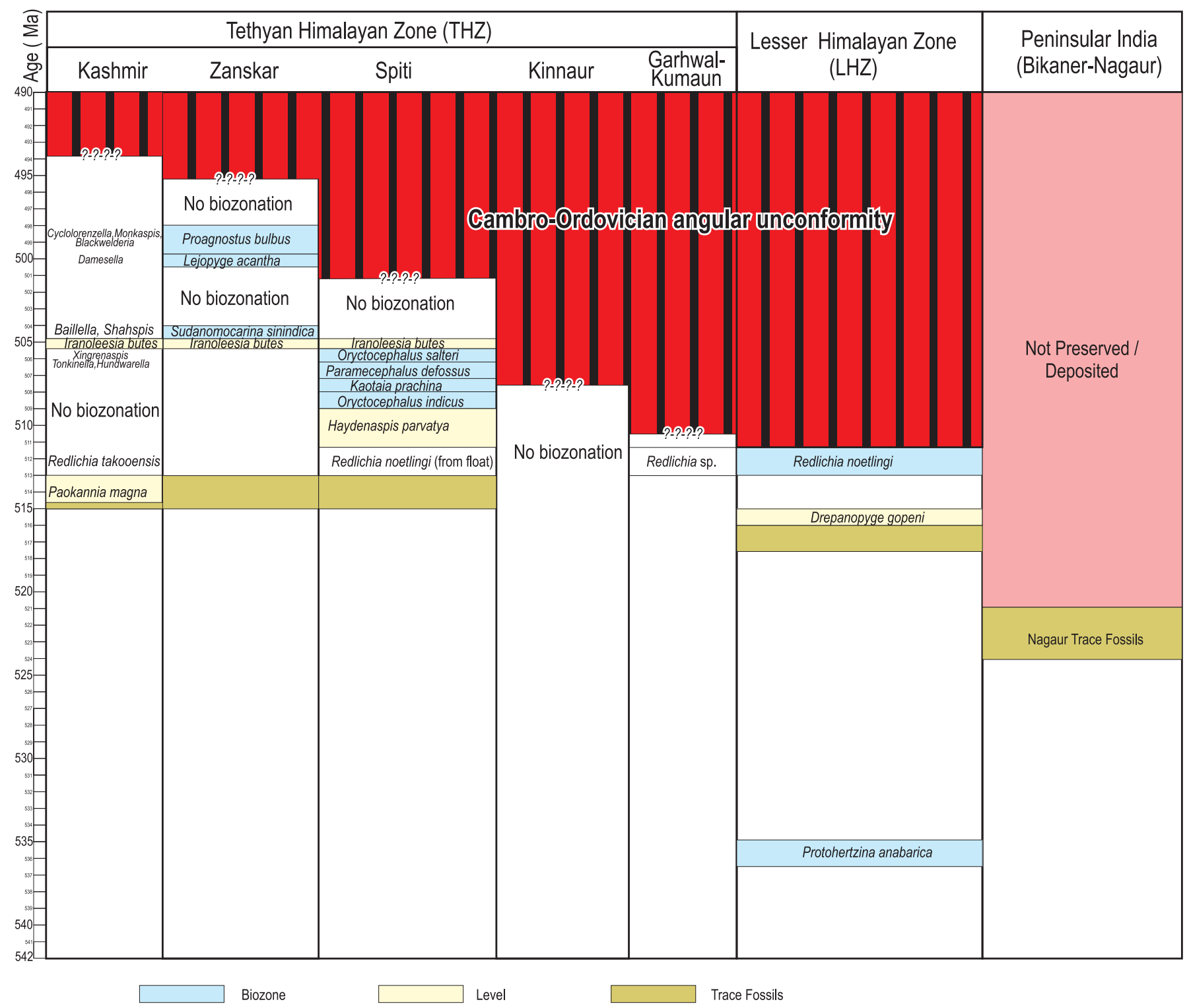


float, thereby the lower age limit of the Cambrian deposits in the Parahio, Sumna and the Pin valleys also stay undated. A thick succession below the $O$. indicus biozone ( $509 \mathrm{Ma})$ is well preserved in the Sumna and the Pin valleys where more work is required.

Biozonation in the Zanskar region is available for the $\sim 505 \mathrm{Ma}$ to $\sim 498 \mathrm{Ma}$ interval, which includes ?Iranoleesiabutes level, Sudanomocarinasinindica, Lejopyge acantha and Proagnostus bulbus biozones (Singh, 2008, 2011; Hughes et al., 2008; Peng et al., 2009; Hughes, 2016).

The biozonation in the Kashmir region has also been updated (Jell and Hughes, 1997; Peng et al., 2009). The available data enable recognition of five intervals: (i) Paokannia magna level ( $\sim 514 \mathrm{Ma})$, (ii) Redlichia noetlingi biozone ( $513-512 \mathrm{Ma}$ ), (iii) Oryctocephalus salteri (506 Ma), (iv) Iranoleesia butes level (505 Ma) and (v) Blackwelderia-Cyclolorenzella ( 505 Ma to 498 Ma) (Jell and Hughes, 1997; Peng et al., 2009).

From Kumaun region (THZ), Redlichid trilobite is known (Kacker and Srivastava, 1996; Myrow et al., 2018), whose proper identification is not possible due to its poor state of preservation.

In LHZ, the Cambrian biozonation is available at four intervals, i.e., at Protohertzina anabarica biozone ( $\sim 42-535 \mathrm{Ma})$, an informal halkieriid-bearing biozone ( 524-516 Ma), Drepanopyge gopeni level ( $\sim 516 \mathrm{Ma}$ ), and Redlichia noetlingi biozone ( 513-512 Ma). Rocks younger than $\sim 512$ Ma are not preserved due to pre-Ordovician erosion (Singh et al., 2019b).

So far rocks of the $\sim 541$ to $\sim 514 \mathrm{Ma}$, that span the most important Ediacaran-Cambrian boundary, have not been identified in the THZ. Earlier reports of the Ediacaran-Cambrian fauna from the Kashmir region have been revised (Singh et al., 2019a), consequently, the lower age limit of the Cambrian sediments in THZ cannot be fixed. Presence or absence of these rocks has a direct bearing on the Cambrian palaeogeographic reconstruction of the THZ and LHZ.

Excellent Cambrian outcrops are available for studies in Lahaul, Kinnaur and Kumaun-Garhwal regions. However, extensive studies, similar to those in the Parahio valley (Spiti), have not been undertaken in these regions due to hostile terrain and paucity of Cambrian workers.

\section{Biozonation in the Peninsular India}

The Marwar Supergroup ( 1200 m thick) in the Bikaner-Nagaur Basin represents a Neoproterozoic to early Cambrian sequence (Khan, 1971; Pareek, 1984). It is divisible into the Jodhpur, Bilara and Nagaur groups. The Nagaur Group in ascending order is divisible into the Nagaur Sandstone and the Tunklian Sandstone. Cambrian trace fossils representing Cruziana ichnofacies are known from the Nagaur Sandstone (Kumar and Pandey, 2008, 2010; Singh et al., 2014; Pandey et al., 2014; Sharma et al., 2018) together with articulated arthropod tergites (Singh et al., 2013) and serially repeated Rusophycus and intergrading Cruziana association (Chaubey and Singh, 2011). Abundant specimens of Treptichnus pedum made by priapulid like worms have been recorded from the Nagaur Sandstone (Srivastava, 2012), which are assigned to the Ediacaran-Cambrian boundary interval.

The age of the Nagaur Sandstone is unresolved and the proposed ages vary from (i) early Cambrian (Kumar and Pandey, 2008, 2010; Singh and Chaubey, 2011; Chaubey and Singh, 2011; Singh et al., 2013), (ii) Ediacaran-Cambrian boundary interval ( 541 Ma) (Srivastava, 2012), (iii) Terreneuvian to Stage 2 ( 526 to $521 \mathrm{Ma})$ (Pandey et al., 2014; Singh et al., 2014;Singh et al., 2019a), and (iv)
Cambrian Series 2, Stage 4 ( 511 Ma) (Hughes, 2016; Sharma et al., 2018).

\section{Biogeographic provinces}

The Indian Cambrian faunal elements share Gondwanan and periGondwanan affinities. As the lower part of the Cambrian ( 541-515 Ma) has not been documented in the THZ, the affinity of this interval is disputable (Singh et al., 2019a). The Paokannia magna level (513$514 \mathrm{Ma}$ ) constitutes the oldest trilobite level recorded in Kashmir (THZ), which shows affinities with that of China. Haydenaspis parvatya level ( 512-510 Ma) in Spiti contains faunal contents similar to those known from the North and the South China (Peng et al., 2009; Kaur et al., 2019). The faunal content of 509-498 Ma (Miaolingian Series, =Middle Cambrian) is comparatively well documented in the Spiti and partially in the Kashmir and the Zanskar regions (Jell and Hughes, 1997; Peng et al., 2009; Singh, 2013; Singh et al., 2016; 2017a, 2017b; Hughes, 2016; Yin et al., 2018). The trilobite fauna of 509-500 Ma interval including Oryctocephalus indicus biozone, Kaotaia prachina biozone, Paramecephalus defossus biozone, Oryctocephalus salteri biozone, Iranoleesia butes level, Sudanomocarinasin indica biozone, Lejopyge acantha biozone and Proagnostus bulbus biozone shows close proximity to the North and the South China peri-gondwanan outboard terranes and to the Europe, Siberia, Kazakhstan, and North America. The $\sim 497$ to 485 Ma rocks were either not deposited or might have been eroded prior to the Cambro-Ordovician unconformity.

The Cambrian interval ( 541-513) of the LHZ shows interesting paleobiogeograpy. The faunal content of LHZ of 541-513 Ma interval shows close affinity to the peri-Gondwana block of the South China (Hughes et al., 2005) and Gondwanan blocks of Egypt and Jordan (Singh et al., 2019a). The arthropod/trilobite traces ( 516-513 Ma), i.e., Cruziana salomonis, Cruziana fasciculata, Rusophycus burjensis and Rusophycus dispar from the LHZ (Singh et al., 2019a) show close affinity with those described from Jordan, Egypt, Turkey and Canada. A Gondwanan to peri-gondwanan affinities recorded from the Lower Quartzite-Shale members to Arkosic Sandstone Member (now a part of the Deona Formation) (Singh et al., 2019a, 2019b). It is attributed to a post-Lower Quartzite Member (Koti Dhaman Formation) tectonic activity that led to the shift of bioprovincialism.

Trilobite faunal elements in the LHZ are poorly known from two levels, i.e., (i) Drepanopyge gopeni level ( 516 Ma) and (ii) Redlichia noetlingi (also including Xela mathurjoshi) ( 512 Ma); their faunal contents show close affinity with that of South China (Hughes et al., 2005). The genus Redlichia ( 512 Ma) is known from Kashmir, Spiti and Kumaun in THZ and the Nigalidhar syncline in LHZ (Kumar and Verma, 1987; Kacker and Srivastava, 1996; Kumar et al., 1987) and from a float in Spiti (Hayden, 1904; Reed, 1910). This genus is well known from the peri-gondwanan terrains mainly from Australia and South China. The genus Xela is well known from Australia.

\section{Cambrian Depositional environment}

Previous studies of the Cambrian sediments of the THZ and the LHZ show a wide array of depositional settings. Only the Cambrian of the Zanskar-Spiti regions (THZ) and the Nigalidhar-Mussoorie synclines (LHZ) have been studied for the depositional settings. Brookfield (1993), Myrow et al. (2003), Hughes et al. (2005); Peng et al. (2009) and Hughes, (2016) suggested that the Cambrian rocks 
of the Tethyan and Lesser Himalayan zones were deposited in a continuous margin of the Indian plate, representing distal to proximal facies respectively. However, Bhargava and Bassi (1998), DeCelles et al. (2000), Bhargava, (2011), Bhargava et al. (2011), Martin (2017) and Singh et al. (2019a) favoured two different settings for these zones. Broadly, the so far studied intervals of the Cambrian period in THZ and LHZ are: 512-505 (in Spiti), 506-498 (in Zanskar) and 541-512 Ma (in Nigalidhar and Mussoorie synclines).

The Cambrian sediments in the Zanskar-Spiti regions are classified into the Batal (?Proterozoic-?early Cambrian), Kunzam La (includes Parahio Member) ( 512 Ma-505 Ma), Karsha ( 506-501 Ma) and Kurgiakh ( 501-498 Ma) formations. The Phe Formation in Zanskar includes the Batal as well as the Kunzam La formations.

The Batal Formation (?Proterozoic-?early Cambrian) in the Zanskar-Spiti region is interpreted to manifest peritidal, partly inter-tidal setting in somewhat poorly circulated basin (Srikantia and Bhargava, 1998; Bhargava and Bassi, 1998; Bhargava, 2008). The sedimentary structures in the Batal Formation are ripple marks, lenticular bedding and local graded bedding of limited thickness.

In the Udaipur region (Chamba syncline), the term Phe has been used for a sandstone/shale sequence, with carbonate beds towards the top (Draganits et al., 2008) and equated with the Batal and Kunzam La formations of the Spiti region, though no fossils have been reported. Draganits et al. (2008) interpreted as the "Phe Formation" of the Chamba represents gravity flow sediments of non-channelized midfan to outer-fan depositional environments. This formational unit requires an in-depth probe for interpreting the depositional settings in Zanskar-Spiti regions.

The Kunzam La Formation in the Zanskar-Spiti regions is variably interpreted in term of depositional settings. Some workers suggested that the Kunzam La Formation of the Spiti region was deposited in deeper-water euxinic (flysch facies) to shallow-water environments (Srikantia, 1981; Fuchs, 1982; Srikantia and Bhargava,1983; Parcha et al., 2005). Bhargavaet al. (1982, 1986) and Bhargava and Bassi (1998) suggested intertidal to subtidal environmental setting on the basis of sedimentary structures like cross-bedding, ripple marks, wavy ripples, lenticular bedding, low angle truncations, channel fill deposits of sands and syndepositional slumps. Garzanti et al. (1986) and Gaetani et al. (1986) considered the Kunzam La Formation is dominated by tidal-flat deposits. Myrow et al. (2006a, b) interpreted the Kunzam La Formation of the Zanskar-Spiti region to represent a siliciclastic deltaic deposit with switching deltaic lobes that contain numerous medium scale shoaling cycles ranging from storminfluenced offshore deposits to thick trough cross-bedded fluvial facies deposited under high rate of sedimentation. They identified waveripple laminations, hummocky cross-stratification (HCS), parallel lamination, parting lineation, symmetrical ripples, interference ripples, ball and pillow structures, pod and gutter casts in the Cambrian sediments of Zanskar-Spiti. Myrow et al. (2006a, 2006b) interpreted the carbonate beds to belong to transgressive systems tract (TST). Bhargava (2008, 2011) inferred low energy, mainly sub-tidal environment with mild bottom currents in basal part, storm influenced in middle part and inter-tidal to tidal flat. Virmani et al. (2015)studied the integrated ichnofabric and lithofacies and proposed a shallow marine wave dominated shoreface to offshore depositional setup in the Spiti region.

The Karsha and the Kurgiakh formations are recognised only in the Zanskar region and northern Lahaul (near Baralacha La). The lower part (Thidsi Member) contains abundant stromatolites which have been interpreted to represent a subtidal environment with a low terrigenous influx (Nanda and Singh, 1977). The upper part (Teta Member) is interpreted to indicate increase in water depth, from peritidal to outer shelf environment, and therefore represents a deepening upwards sequence (Gaetani et al., 1985). Garzanti et al. (1986) and Gaetani et al. (1986) considered the transition from Karsha to Kurgiakh formations to represent a sequence of basinal turbidites developed as a response to tectonically induced subsidence associated with development of a foreland basin. Myrow et al. (2006b) suggested that the Karsha Formation records a transition from siliciclastic- to carbonate-dominated strata, representing a long-term decrease in supply of terrigenous detritus. Myrow et al. (2006b) interpreted deposition of the Kurgiakh Formation in a shallow-marine, storminfluenced environments. They interpreted that although the Karsha carbonate platform might have been drowned, it did not culminate in deep-sea flysch deposition.

The Cambrian sequences in the LHZ have been considered proximal equivalent of the THZ (Brookfield, 1993; Searle, 1986; Myrow et al., 2003, 2006a, 2006b; 2009; Hughes et al., 2005, 2018; Hughes, 2016). However, on the other hand, Saxena (1971), Bhargava et al. (1998, 2011), DeCelles et al. (2000); Bhargava (2008, 2011), Martin (2017), and Singh et al. (2019a) have suggested two different settings for the deposition of the Cambrian sequences in the LHZ and THZ.

The Tal Group in the LHZ shows variable conditions of deposition from the Garhwal syncline (very shallow water condition) to the Nigalidhar syncline (shallow-to deep water settings). Overall, most of the basal part of the Tal Group in these synclines begins with the phosphate bearing cherty succession (phosphorite in Mussoorie syncline), which was interpreted to have been deposited under restricted circulation over an uneven topography (Shanker, 1971; Bhargava et al.,1998) having an indirect connection with an open sea, which provided phosphate-rich upwelling currents (Bhargava, 2011). Mazumdar et al. (1999) interpreted that the chert-phosphorite in Mussoorie syncline record negative Ce and positive Eu anomalies. While Ce is an important paleooceanic redox indicator, Eu is rather immobile under normal diagenetic conditions. Hughes (2016) considered it to represent a condensed section. The black argillaceous shale overlying the chert successions is interpreted to represent euxinic condition. The arenaceous rocks of the Tal Group exhibit abundant trough and planar cross-bedding, flaser and lenticular beddings, rippled surfaces, reactivation surfaces and are interpreted to represent tidal-flat complex setting (Bhargava et al., 1998; Singh et al., 2019a). These rocks in the Mussoorie syncline based on clay mineral analysis are interpreted to have been deposited under shallow marine conditions (Ganesan, 1975). Singh et al. (2019a) based on sequence stratigraphy studies of the Koti Dhaman Formation (upper part of the Tal Group, Nigalidhar syncline) suggested that the Koti Dhaman Formation (from Lower Quartzite Member to Shale Member) represents compound dunes and sand sheets (sub-tidal), sand flat (tidal flat complex), migration of a sand-sheet complex in shallow sub-tidal environments during regression of a tide-dominated shoreline. The Shale Member was deposited in a mud-dominated tidal-flat setting. The mud flat facies of the Shale Member directly rests on the sand flat facies of the underlying para sequence_-omitting the mixed flat facies, indicating a jump in facies, which is related to a break in sedimentation between the Shale Member and Lower Quartzite Member due to a possible forced-regressive event. 


\section{The Ediacaran-Cambrian boundary}

In the Bikaner Basin (peninsular part), the abundance of Treptichnus pedum in the Nagaur Sandstone (Srivastava, 2012) indicates Ediacaran-Cambrian boundary interval in close proximity.In the LHZ, the presence of tuffites, glass and devitrified glass fragments in the Earthy Siltstone Member (Shaliyan Formation, Tal Group, Bhargava et al., 1998) were regarded to manifest Neoproterozoic PanAfrican volcanism by Bhargava et al. (1998), who advocated placing of the Ediacaran-Cambrian boundary at the base of the overlying Chert Member, which has yielded rich small shelly fossils (SSFs) in the Mussoorie syncline and its fragmentary remains in the Nigalidhar Syncline (work under progress). This contention is further substantiated by the discovery of Shaanxilithes ningqiangensis (Tarhan et al., 2014) from the Early Siltstone Member.

\section{Acknowledgements}

Thanks are due to Prof. G.V.R. Prasad (Delhi University) for inviting us to contribute to the IGC-36 volume. The IGC-36 funding for preparation of field excursion guide for Renuka-Sector (part of NR008) is gratefully acknowledged.

We are thankful to Dr. Radek Mikuláš (Institute of Geology, Czech Academy of Sciences) and Dr. S.K.Tangri (Retd. Dy. Director General, Geological Survey of India) for constructive comments which improved the manuscript.

\section{References}

Ahmad, S., and Kumar, S., 2014, Trace fossil assemblage from the Nagaur Group, Western India. Journal Palaeontological Society of India, v. 59 (2), pp. 231-246.

Auden, J.B., 1934, The Geology of the Krol belt. Record Geological Survey of India, v. 67 (4), pp.357-454.

Auden, J.B., 1937, The structure of the Himalaya in Garhwal. Record Geological Survey of India, v. 71, pp. 407-433.

Azmi, R.J., Joshi, M.N., and Juyal, K.P., 1981, Discovery of the Cambro-Ordovician conodonts from the Mussoorie Tal phosphorite: its significance in correlation of the Lesser Himalaya. In: Sinha, A.K. (Ed.), Contemporary Geoscientific Researches in Himalaya. I, 245-249.

Bhargava, O.N., 1972, A reinterpretation of the Krol Belt. Himalayan Geology, v. 2, pp. 47-81.

Bhargava, O.N., 1976, Geology of the Krol Belt and associated formations: a reappraisal. Memoirs Geological Survey of India, v. 20(1), pp.167-234.

Bhargava, O.N., 1979, Lithostratigraphic classification of the Blaini, Infra-Krol and Tal formations- A review. Journal Geological Society of India, v. 20, pp.7-16.

Bhargava, O.N., 1984, Trace fossil from the Cambrian Tal Group, Sirmaur district, H.P. and proposed redefinition of the Tal. Journal Palaeontological Society of India, v. 29, pp. 84-87.

Bhargava, O.N., 2008, An updated introduction to the Spiti geology. Journal Palaeontological Society of India, v. 53 (2), pp. 113129.

Bhargava, O.N., 2011, Early Palaeozoic palaeogeography, basin configuration, palaeoclimate and tectonics in the Indian Plate. Memoir Geological Society of India, v. 78, pp. 69-99.

Bhargava, O.N., and Bassi, U.K., 1998, Geology of Spiti- Kinnaur Himachal Himalaya. Memoir Geological Survey of India, v. 124, pp. 1-210.
Bhargava, O.N., Bhandari, A.K., and Sharma, R.K., 1986, Lower Cambrian trace fossils from the Kilung Valley, Lahaul and Spiti District, Himachal Himalaya. Bulletin Indian Geologists' Association, v.19, pp. 66-68.

Bhargava, O.N., Frank, W., and Bertle, R., 2011, Late Cambrian deformation in the Lesser Himalaya. Journal Asian Earth Sciences, v. 40, pp. 201-212.

Bhargava, O.N., Kumar, G., and Gupta, S.S., 1982, Cambrian trace fossils from the Spiti Valley, Himachal Himalaya. Journal Geological Society of India, v. 23, pp. 183-191.

Bhargava, O.N., Singh, I., Hans, S.K., and Bassi, U.K., 1998, Early Cambrian trace and trilobite fossils from the Nigali Dhar Syncline (Sirmaur District, Himachal Pradesh), lithostratigraphic correlation and fossil content of the Tal Group. Himalayan Geology, v. 19, pp. 89-108.

Bhatt, D.K., Mamgain, V.D., Misra, R.S., and Srivastava, J.P., 1983, Shelly microfossils of Tommotian age (Lower Cambrian) from the Chert-Phosphorite Member of Lower Tal Formation, Maldeota, Dehra Dun District, Uttar Pradesh. Geophytology, v. 13, pp. 116-123.

Bhatt, D.K., Mamgain, V.D., and Misra, R.S., 1985, Small shelly fossils of Early Cambrian (Tommotian) age from Chertphosphorite Member, Tal Formation, Mussoorie syncline, Lesser Himalaya, India and their chronostratigraphic evaluation. Journal Palaeontological Society of India, v. 30, pp. 92-102.

Brasier, M.D., and Singh, P., 1987, Microfossils and PrecambrianCambrian boundary stratigraphy at Maldeota, Lesser Himalaya. Geological Magazine, v. 124, pp. 323-345.

Brookfield, M.E., 1993, The Himalayan passive margin from Precambrian to Cretaceous times. Sedimentary Geology, v. 84, pp. 1-35.

Chaubey, R.S., and Singh, B.P., 2011, Occurrence of serially repeated Rusophycus and integrated Cruziana association from early Cambrian Nagaur sandstone Formation of Marwar super-group, Bikaner, Rajasthan and their significance. World Conference on Paleontology and Stratigraphy (WCPS), 78-79.

DeCelles, P.G., Gehrels, G.E., Quade, J., LaReau, B., and Spurlin,M., 2000, Tectonic implications of U-Pb zircon ages of the Himalayan orogenic belt in Nepal. Science, v. 288, pp. 497-499.

Desai, B.G., Shukla, R., and Saklani, R.D., 2010, Ichnology of the Early Cambrian Tal Group, Nigalidhar Syncline, Lesser Himalaya India. Ichnos, v. 17, pp.233-245.

Draganits, E., Schlaf, J., Grasemann, B., and Argles, T., 2008, Giant submarine landslide grooves in the Neoproterozoic/Lower Cambrian Phe Formation, northwest Himalaya: Mechanisms of formation and palaeogeographic implications. Sedimentary Geology, v. 205, pp. 126-141.

Fuchs, G., 1982. The geology of the Pin Valley in Spiti, H.P.India. Jahrbuch der Geollogischen Bundessanstalt, v. 124(2), pp. 325359.

Gaetani, M., Garzanti, E., and Jadoul, F.,1985, Main structural elements of Zanskar, NW Himalaya (India). Rendiconti della Societa Geologica Italiana, v. 8, pp. 3-8.

Gaetani, M., Casnedi, R., Fois, E., Garzanti, E., Jadaul, F., Nicora, A., and Tintori, A., 1986, Stratigraphy of the Tethyan Himalaya in Zanskar, Ladakh. Rivista Italaliana di Paleontologia e Stratigraphia, v. 91(4), pp. 443-478.

Ganesan, T.M., 1975, Paleocurrent pattern in the upper Tal rocks of Nigali, Korgai synclines (H.P.) and Mussoorie syncline (U.P.). Journal of the Geological Society of India, v. 16, p. 503-507.

Garzanti, E., Casnedi, R., Jadoul, F., 1986, Sedimentary evidence of a Cambro-Ordovician orogenic event in the Northwestern Himalaya. Sedimentary Geology, v. 48, pp. 237-265.

Garzanti, E., Jadoul, F., Nicora, A., and Berra, F., 1996, Triassic of 
Spiti (Tethys Himalaya), N. India. Rivista Italaliana di Paleontologia e Stratigraphia, v. 101(3), pp. 267-300.

Gilbert, I.R., Hughes, N.C., and Myrow, P.M., 2016, Cambrian microfossils from the Tethyan Himalaya. Journal of Paleontology, v. 90, pp. 10-30.

Hayden, H.H., 1904, The Geology of Spiti with parts of Bashahr and Rupshu. Memoir Geological Survey of India, v. 36, pp. 1-121.

Hughes, N.C., 2016, The Cambrian palaeontological record of the Indian subcontinent. Earth Science Reviews, v. 159, pp.428-461.

Hughes, N.C., Myrow, P.M., McKenzie, N.R., Harper, D.A.T., Bhargava, O.N., Tangri, S.K., Ghalley, K.S., and Fanning, C.M., 2011, Cambrian rocks and fauna of the Wachi La, Black Mountains, Bhutan. Geological Magazine, v. 148, pp. 351-379.

Hughes, N.C., Myrow, P.M., Ghazi,S., McKenzie, N.R., Stockli, D.F., and DiPietro, J.A., 2018, Cambrian geology of the Salt Range of Pakistan: Linking the Himalayan margin to the Indian craton. Geological Society of America Bulletin. https://doi.org/10.1130/ B35092.1.

Hughes, N.C., Peng, S.C., Bhargava, O.N., Ahulwalia, A.D., Walia, S., Myrow, P.M., and Parcha, S.K., 2005, The Cambrian biostratigraphy of the Tal Group, Lesser Himalaya, India, and early Tsanglangpuan (late early Cambrian) trilobites from the Nigali Dhar syncline. Geological Magazine, v.142, pp. 57-80.

Hughes, N.C., Peng, S. and Parcha, S.K., 2008, Cambrian trilobites from the Parahio and Zanskar valleys, Indian Himalaya: A synopsis. In: I. Rábano, R. Gozalo and D. García Bellido (Eds.) Advances in trilobite research. Cuadernos del Museo Geominero, $n^{\circ}$ 9. Instituto Geológico y Minero de España, Madrid, p. 199.

Jell, P.A., and Hughes, N.C., 1997, Himalayan Cambrian trilobites. Special Papers in Palaeontology, v. 58, pp. 1-113.

Joshi, A., Mathur, V.K., and Bhatt, D.K., 1989, Discovery of redlichid trilobites from the Arenaceous Member of the Tal Formation, Garhwal syncline, Lesser Himalaya, India. Journal Geological Society of India, v. 33(6), pp.538-546.

Juyal, K.P., 1979, A report of geological field work of SimlaChandigarh-Bhakra Dam and Maldeowata phosphorite mine. Unpub., MS report, D.S.B. College, HNB Garhwal University, Srinagar, figs.13, pl.4, pp. 1-37.

Kacker, A.K., and Srivastava, M.C., 1996, Redlichia from Milam Formation of Martoli Group, Kumaon Himalaya, Indiasystematics and signiûcance. Proceedings of Symposium on Recent Advances in Geological Studies of Northwest Himalaya and the Foredeep. Journal Geological Survey India Special Publication, v. 21, pp. 291-293.

Kaur, R., Singh, B.P., Bhargava, O.N., Singla, G., and Stopden, S., 2019, Cambrian trilobite fauna of the Haydenaspis parvatya level (Series 2, Stage 4): its stratigraphic position with respect to the Oryctocephalus indicus Biozone (Miaolingian Series, Wuliuan Stage) in the Spiti Himalaya, India. Competes PaloeVol,v.18, pp. 298-305.

Khan, E.A., 1971, Geological mapping in parts of Jodhpur and Nagaur districts, Rajasthan. Field session 1969-1970. Unpublished report. Geological Survey of India.

Kobayashi, T., 1934. Middle Cambrian fossils from Kashmir. American Journal Science, v. 27, pp. 295-302.

Kumar, S., and Pandey, S.K., 2008, Discovery of trilobite trace fossils from the Nagaur Sandstone, the Marwar Supergroup, Dulmera area, District Bikaner, Rajasthan. Current Science, v.94, pp.10811085.

Kumar, S., and Pandey, S.K., 2010, Trace fossils from the Nagaur Sandstone, Marwar Supergroup, Dulmera area, Bikaner district, Rajasthan, India. Journal Asian Earth Science, v.38, pp. 77-85.

Kumar, G., and Singh, G., 1983, Middle Cambrian trilobites from Karihul, Liddar Valley, Anantnag district, Kashmir and its significance. Current Science, v. 52, pp. 548-549.

Kumar, G., and Verma, R.N., 1987, Early Cambrian (Tsanglangpuian Stage) trilobites from Vel Nagabal, Anantnag District, Jammu and Kashmir, India. Journal Palaeontological Society of India, v. 32, pp. 131-135.

Kumar, G., Joshi, A., and Mathur, V.K., 1987, Redlichiid trilobites from the Tal Formation, Lesser Himalaya, India. Current Science, v. 56, pp. 659-663.

Martin, A.J., 2017, A review of Himalayan stratigraphy, magmatism, and structure. Gondwana Research, v. 49, pp.42-80.

Mathur, V.K., and Joshi, A., 1989, Record of redlichiid trilobite from the Lower Cambrian Tal Formation, Mussoorie Syncline, Lesser Himalaya, India. Journal Geological Society of India, v. 33, pp. 268-270.

Mazumdar, A., Banerjee, D.M., Schidlowski, M., Balaram, V., 1999. Rare-earth elements and Stable Isotope Geochemistry of early Cambrian chert-phosphorite assemblages from the Lower Tal Formation of the Krol Belt (Lesser Himalaya, India). Chemical Geology, v. 156(1-4), pp. 275-297.

Medlicott, H.B., 1864, On the geological structure and relation of the southern portion of the Himalayan ranges between the rivers Ganges and the Ravee. Memoir Geological Survey of India, v. 3(2), pp. 1-212.

Middlemiss, C.S., 1887, Physical geology of west British Garhwal with notes on the route traverse through Jaunsar-Bawar and Tehri Garhwal. Record Geological Survey of India, v. 20, pp.26-40.

Myrow, P.M., Hughes, N.C., Paulsen, T.S., Williams, I.S., Parcha, S.K., Thompson, K.R., Bowring, S.A., Peng, S.C., and Ahluwalia, A.D., 2003, Integrated tectonostratigraphic reconstruction of the Himalaya and implications for its tectonic reconstruction. Earth Planetary Science Letter, v. 212, pp. 433-441.

Myrow, P.M., Thompson, K., Hughes, N.C., Paulsen, T.S., Sell, B.K. and Parcha, S.K.,2006a, Cambrian stratigraphy and depositional history of Northern Indian Himalaya, Spiti Valley, north-Central India. Bulletin of Geological Society of America, v. 118 (3/4), pp. 491-510.

Myrow, P.M., Snell, K.E., Hughes, N.C., Paulsen, T.S., Heim, N.A., and Parcha, S.K., 2006b, Cambrian Depositional History of the Zanskar Valley Region of the Indian Himalaya: Tectonic Implications. Journal of Sedimentary Research, v. 76, pp.364381.

Myrow, P.M., Hughes, N.C., Searle, M.P., Fanning, C.M., Peng, S.C., and Parcha, S.K., 2009, Stratigraphic correlation of CambrianOrdovician deposits along the Himalaya: implications for the age and nature of rocks in the Mt. Everest region. Geological Society American Bulletin, v.120, pp. 323-332.

Myrow, P.M., Hughes, N.C., Goodge, J.W., Fanning, C.M., Peng, S.C., Bhargava, O.N., Tangri, S. K., Parcha, S.K., and Pogue, K.R., 2010, Extraordinary transport and mixing of sediment across Himalayan central Gondwanaland during the CambrianOrdovician. Geological Society American Bulletin, v. 122, pp. 1660-1670.

Myrow, P.M., Hughes, N.C., McKenzie, N.R., Pelgay, P., Thompson, T.J., Haddad, E.E., and Fanning, C.M., 2016, CambrianOrdovician orogenesis in Himalayan equatorial Gondwana. Geological Society American Bulletin, http://dx.doi.org/10.1130/ B31507.1.

Myrow, P.M., Hughes. N.C., and McKenzie, N.R., 2018, Reconstructing the Himalayan margin prior to collision with Asia: Proterozoic and lower Paleozoic geology and its implications for Cenozoic tectonics. Geological Society London Special Publications, DOI: 10.1144/SP483.10.

Nanda, M.M., and Singh, M.P., 1977,Stratigraphy and sedimentation of the Zanskar area, Ladakh and adjoining parts of the Lahaul 
region of Himachal Pradesh. Himalayan Geology, v. 6, pp.365388.

Noetling, F., 1894, On the Cambrian Formation of the Eastern Salt Range. Record Geological Survey of India, v. 27 (3), pp. 71-86.

Pandey, D.K., Uchmann, A., Kumar, V., and Shekhawat, R.S., 2014, Cambrian fossil of the Cruziana ichnofacies from Bikaner-Nagaur basin, north west Indian craton. Journal Asian Earth Sciences, v. 81, pp. 129-141.

Parcha, S.K., Singh, B.P., and Singh, B.P., 2005, Paleoecological significance of ichnofossils from the early Cambrian succession of the Spiti Valley, Tethys Himalaya, India. Current Science, v. 88(1), pp.158-161.

Pareek, H.S., 1984, Pre-Quaternary geology and mineral resources of north western Rajasthan. Memoir Geological Survey of India, v. 115, pp. 1-95.

Peng, S.-C, Hughes, N.C., Heim, N.A., Sell, B.K., Zhu, X., Myrow, P.M., and Parcha, S.K., 2009, Cambrian trilobites from the Parahio and Zanskar Valleys, Indian Himalaya. Paleontological Society Memoir, v. 71, pp. 1-95 (supplement to the Journal Paleontology).

Popov, L.E., Holmer, L.E., Hughes, N.C., Ghobadi Pour, M., and Myrow, P.M., 2015, Himalayan Cambrian Brachiopods. Papers in Palaeontology, v. 1 (4), pp. 345-399.

Prasad, B., Maithy, P.K., Kumar, G., and Raina, B.K., 1990, Precambrian-Cambrian acritarchs from the Blaini-Krol-Tal sequence of Mussoorie Syncline, Garhwal Lesser Himalaya, India. Memoir Geological Society of India, v. 16, pp. 19-32.

Redlich, K.A., 1899, The Cambrian fauna of the eastern Salt-Range. Palaeontologia Indica, New Series, v. 1(1), pp. 1-13.

Reed, F.R.C., 1910, The Cambrian fossils of Spiti. Palaeontologia Indica, Series, v. 7, pp. 1-70.

Reed, F.R.C., 1934, Cambrian and Ordovician fossils from Kashmir. Palaeontologia Indica, v. 21(2), pp. 1-38.

Saxena, M.N., 1971, The crystalline axis of the Himalaya: The Indian shield and continental drift. Tectonophysics, v.12(6), p. 433-447.

Schindewolf, O.H., and Seilacher, A., 1955, Beiträge zur Kenntnis des Kambriums in der Salt Range (Pakistan). Akademie der Wissenschaften und der Literatur. Mainz Mathematischnaturwissenschaûichen Klasse Abhandlungen, v. 10, pp. 261-446.

Searle, M.P., 1986, Structural evolution and sequence of thrusting in the High Himalayan, Tibetan-Tethys and Indus suture zones of Zanskar and Ladakh, Western Himalaya. Journal of Structural Geology, v. 8, pp. 923-936.

Shah, S.K., 1982, Cambrian stratigraphy of Kashmir and its boundary problems. Precambrian Research, v. 17, pp. 87-98.

Shah, S.K., 1993, Cambrian biofacies and faunal provinces of Himalaya. Journal Palaeontological Society of India, v.38, pp.3742.

Shah, S.K., Raina, B.K., and Razdan, M.L., 1980, Redlichid fauna from the Cambrian of Kashmir. Journal Geological Society of India, v. 21, pp. 511-517.

Shah, S.K., Sudan, C.S., Parcha, S.K., and Raina, A.K., 1988, Revision of the genus Hundwarella Reed and its signiûcance in Himalayan Cambrian. Journal Palaeontological Society of India, v. 33, pp. 47-58.

Shah, S.K., Parcha, S.K., and Raina, A.K., 1991, Late Cambrian trilobites from Himalaya. Journal Geological Society of India, v. 36, pp. 89-107.

Shanker, R., 1971, Stratigraphy and sedimentation of Tal Formation Mussoorie syncline, U.P. Journal Paleontological Society of India, v.16, pp.1-15.

Sharma, M., Ahmad, S., Pandey, S.K., and Kumar, K., 2018, Behavioural and taphonomical testimony of Treptichnuspedum, inferences from the Nagaur Sandstone, Marwar Super-group, India. Bulletin Geosciences, https://doi.org/10.3140/ bull.geosci.1666.

Singh, I.B., and Rai, V., 1983, Fauna and biogenic structures in KrolTal succession (Vendian-Early Cambrian), Lesser Himalaya: Their biostratigraphic and palaeoecological significance. Journal Palaeontological Society of India, v. 28, pp.67-90.

Singh, B.P., 2008, Additional Cambrian trilobites from Kurgiakh valley Zanskar basin, northwest Himalaya. In: I.Rábano, R. Gozalo and D. García-Bellido (Eds.), Advances in Trilobite Research. Cuadernos del Museo Geominero, Instituto Geológico y Minero de España, Madrid, No. 9, pp.365-369.

Singh, B.P., 2011, Latest middle Cambrian trilobites from the Teta Member of the Karsha Formation (Haimanta Group), Zanskar region, northwest Himalaya, India. Memoir Geological Society of India, v. 78, pp. 14-28.

Singh, B.P., 2013, Additional Late Middle Cambrian Trilobites from Karsha Formation (Haimanta Group) Zanskar Region of ZanskarSpiti Basin, Northwest Himalaya. Journal Geological Society of India, v. 81, pp. 361-368.

Singh, B.P., and Chaubey, R.S., 2011, Litho-ichnofacies of the Nagaur Sandstone Formation (Marwar Super-group), Bikaner-Nagaur Basin (Rajasthan). Sediments-2011, Leipzig, 94.

Singh, B.P, Bhargava, O.N, Kishore, N., Ahluwalia, A.D., and Chaubey, R.S., 2013, Arthropod from the Bikaner-Nagaur Basin, peninsular India. Current Science, v. 104(6), pp. 706-707.

Singh, B.P, Bhargava, O.N, Chaubey, R.S., and Kishore, N., 2014, Ichnology and depositional environment of the Cambrian Nagaur Sandstone (Nagaur Group) along the Dulmera section, Bikaner Nagaur Basin, Rajasthan. Acta Geologica Sinica, v. 88(6), pp. 1665-1680.

Singh, B.P., Bhargava, O.N., Juyal, K.P., Negi, R.S., Virmani, N., Sharma, C.A., and Gill, A., 2015, Skeletal microfauna from the Cambrian Series 2 (Stage 4) Kunzum La Formation, Parahio valley, Spiti region (Tethyan Himalaya), India. Current Science, v.109 (12), pp. 2191-2195.

Singh, B.P., Virmani, N., Bhargava, O.N., Negi, R.S., Kishore, N., and Gill, A., 2016, Trilobite fauna of basal Cambrian Series 3 (Stage 5) from the Parahio Valley (Spiti), Northwest Himalaya, India and its biostratigraphic signiûcance. Annals de Palaeontologia, v. 102, pp. 59-67.

Singh, B.P., Chaubey, R.S., Bhargava, O.N., Prasad, S.K., and Negi, R.S., 2017a, The Cambrian trilobite fauna from the Shian (Saybang) section, Pin Valley (Spiti) and its biostratigraphic signiûcance. Palaeoworld, v. 26, pp.25-36.

Singh, B.P., Bhargava, O.N., Negi, R.S., Zhao, Y.-L., Yin, L., and Sharma, C.A., 2017b, Additional trilobite fauna from the basal part of the Cambrian Series 3, Stage 5, Kunzam La (=Parahio) Formation, Parahio Valley, Spiti (Northwest Himalaya), India and its biostratigraphic signiûcance. Annals de Palaeontologia, v. 103, pp. 271-281.

Singh, B.P., Bhargava, O.N., Mikuláš, R., Morrison, S., Kaur, R., Singla, G., Kishore, N., Kumar, N., Kumar, R., and Moudgil, S., 2019a, Integrated sedimentological, ichnological and sequence stratigraphical studies of the Koti Dhaman Formation (Tal Group), NigaliDhar syncline, Lesser Himalaya, India: Paleoenvironment, paleoecologic, palaeogeographic significance. Ichnos, https:// doi.org/10.1080/10420940.2019.1584560.

Singh, B.P., Bhargava, O.N., Mikuláš, R., Prasad, S.K., Morrison, S., Chaubey, R.S., and Kishore, N. 2019b. Discovery of Ordovician trace fossils from the Lesser Himalaya, India: its stratigraphic, tectonic and palaeogeographic implications. Journal Palaeontological Society of India, v. 64(2), pp. 283-303.

Srikantia, S.V. 1981. The lithostratigraphy, sedimentation and structure of the Proterozoic-Phanerozoic of the Spiti Basin in the Higher Himalaya of Himachal Pradesh, India. In: Sinha, A.K. 
(Ed.),Contemporary Geoscientific Research in the Himalaya. Bishen Singh Mahinder Pal, Dehradun, v.1, pp. 31-48.

Srikantia, S.V., and Bhargava, O.N., 1983, An outline of the structure of the area between the Rohtang Pass in Lahaul and Indus Valley in Ladakh. Miscellaneous Publication of Geological Survey of India, v. 41 (3), pp. 183-203.

Srikantia, S.V., and Bhargava, O.N., 1998, Geology of Himachal Pradesh. Journal Geological Society of India, 1-435p.

Srikantia, S.V., and Bhargava, O.N., 2018, Stratigraphic nomenclatures of early Paleozoic in the Spiti, Himalaya: Cobwebs removed. Journal of the Palaeontological Society of India, v. 63(2), pp. 23-34.

Srikantia, S.V., Ganesan, T.M., Rao, P.N., Sinha, P.K., and Tirkey, B., 1980 (for 1978), Geology of the Zanskar area, Ladakh Himalaya. Himalayan Geol., v.8, pp. 1009-1033.

Srivastava, P., 2012. Treptichnuspedum: An ichnofossil representing Ediacaran-Cambrian Boundary in the Nagaur Group, the Marwar Supergroup, Rajasthan, Proceeding Indian National Science Academy, pp. 78161-78169.

Tangri, S.K., and Pande, A.C., 1995, Tethyan Sequence. In: Bhargava, O.N. (Ed.), The Bhutan Himalaya: a geological account. Special Publication Geological Survey of India, Calcutta, v. 39, pp. 109141.

Tangri, S.K., Bhargava, O.N., and Pande, A.C. 2003, Late Precambrian-Early Cambrian Trace Fossils from Tethyan Himalaya, Bhutan and their Bearing on the PrecambrianCambrian Boundary. Journal Geological Society of India, v. 6, pp.708-716.

Tarhan, L.G., Hughes, N.C., Myrow, P.M., Bhargava, O.N., Ahluwalia, A.D., and Kudryavtsev, A.B., 2014, Precambrian-Cambrian boundary interval occurrence and form of the enigmatic tubular

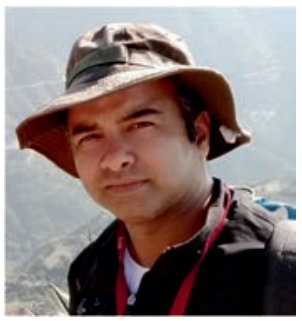

Birendra P. Singh is an Assistant Professor at the Department of Geology (CAS), Panjab University Chandigarh. His contributions pertain to the Cambrian trilobites, chronostratigraphy of the Cambrian Series 3, Stage 5, spatial and temporal distribution of trace fossils and their use in deciphering the palaeoenvironments of the Himalaya and Peninsular India. Recently he has focused on Ediacaran-Cambrian and the boundary between the Cambrian Series 2 and 3 in the Himalaya. He was the first to report Ordovician sediments in the Lesser Himalaya. body fossil Shaanxilithesningqiangensis from the Lesser Himalaya of India. Palaeontology, v. 57, pp. 283-298.

Tiwari, M., 1989, Discovery of pre-trilobite small shelly fossils and position of Precambrian-Cambrian boundary in Tethyan sequence of northwestern Kashmir. Current Science, v. 58, pp. 839-843.

Tiwari, M., 1997, Nabaviellaacanthomorpha n. sp., a sponge spicules from the Precambrian-Cambrian boundary interval in the Tethys sequence of north-western Kashmir. Journal Geological Society of India, v. 50, pp. 655-658.

Upadhyay, R., and Parcha, S.K., 2012, Ichnofossils from the Jadhganga (Nelang) valley, Uttarakashi District, Garhwal Tethys Himalaya, India. Himalayan Geology, v. 33, pp. 83-88.

Virmani, N., Singh, B.P., and Gill, A., 2015, Integrated Lithoichnofacies and ichnofabric analysis of the lowermost part of the Kunzum La Formation along the Khemangar khad and the Parahio Valley sections, Spiti Region (Zanskar-Spiti-Kinnaur Basin), Northwest Himalaya, India. Journal of the Geological Society of India, v. 85, pp. 557-566.

Waagen, W., 1891, Salt Range Fossils. Palaeontologia Indica Series 13, v. 4, pp. 89-242.

Wadia, D.N., 1934, Cambrian-Triassic Sequence of N.W. Kashmir. Record Geological Survey India, v. 68, pt. 2.

Wadia, D.N., 1975, The Geology of India. Tata McGraw-Hill, New Delhi (508 p).

Whittington, H.B., 1986, Late middle Cambrian trilobites from Zanskar, Ladakh, northern India. Rivista Italian Paleontologica Stratigraphica, v. 92, pp. 171-188.

Yin, L.-M., Singh, B.P., Bhargava, O.N., Zhao, Y.-L., Negi, R.S., Meng, F.-W., and Sharma, C.A., 2018, Palynomorphs from the Cambrian Series 3, Parahio valley (Spiti), Northwest Himalaya. Palaeoworld, v. 27, pp. 30-41.

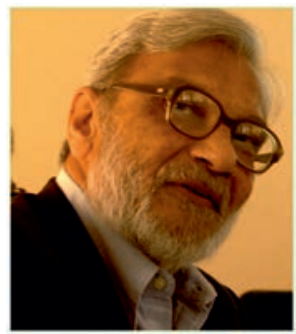

Om N. Bhargava an Honorary Professor and INSA Honorary Scientist at Geology Department of Geology (CAS), Panjab University Chandigarh is concentrating on Palaeozoic and Triassic sequences of the Spiti Valley. Earlier while in the Geological Survey of India, he worked extensively in Himachal Pradesh, Bhutan and parts of Kashmir, and Ladakh. His main interest was regional geology, stratigraphy, tectonics and palaentology. He recorded geoseismological observations of 1975 Kinnaur Earthquake and studied the causes and remedies of glacial lakes bursts in Bhutan as a part of environmental studies. 